\title{
TÜRK KÜLTÜRÜNDE "SELAMLAŞMA" VE "VEDALAŞMA" HAKKINDA GENEL BİR DEĞERLENDİRME
}

\author{
Ahmet KESKIN*
}

\begin{abstract}
Özet:
Bu çalışmada, kişiler arası temel iletişimi sağlayan ve alışılagelmiş niteliği taşıyan "selamlaşma" ve "vedalaşma” eylemlerinin, Türk kültürünün eski çağlarından günümüze kadar nasıl gerçekleştirilmiş olduğu konusu ele alınmıştır. Bu kapsamda öncelikle, günümüzde selamlaşma ve vedalaşma amacıyla yaygın olarak kullanılan söz ve davranış kalıpları üzerinde durulmuştur. Ardından, Türk dili ve kültürü tarihi üzerinde çalışan araştırmacıların konuyla ilgili ortaya koyduğu bilgiler aktarılmış ve bunların değerlendirmesi yapılmıştır. Çalışmanın devamında, günümüzde Türk dünyasının farklı coğrafi bölgelerinde yaşayan Türk boyları arasında tarihî süreçte selamlaşma ve vedalaşma süreçlerinde kullanılan sözcük ve ifadeler, köken özellikleri dikkate alınarak belirli gruplara ayrllmış ve bu gruplar altında incelenmiştir. Ortaya konulan tüm bu verilerden hareketle, Türk kültüründe selamlaşma ve vedalaşma eylemlerinin hangi sözcük, ifade ve davranış kalıplarılla gerçekleştirildiği konusunda ulaşılan sonuçlar paylaşılmıştır. Çalışmanın sonuna, Türk boyları arasında selamlaşma ve vedalaşma işlevinde kullanılan ifadelerin karşılaştırmalı olarak izlenebilmesi için, selamlaşma ve vedalaşma ile ilgili sözcük ve ifadeleri gösteren bir tablo eklenmiştir.
\end{abstract}

Anahtar kelimeler: Türk kültürü, Türk lehçeleri, gündelik yaşam, iletişim, "selamlaşma”, "vedalaşma”.

\section{A General Assessment about "Greeting" and "Saying Good Bye" in Turkish Culture}

\section{Abstarct:}

In this study, the act of "greeting" and "saying goodbye", which make the interpersonal communication possible and gradually becoming common, has been analy-

Arş. Gör., Giresun Üniversitesi Fen-Edebiyat Fakültesi Türk Dili ve Edebiyatı Bölümü Türk Halk Bilimi ABD, ahmetkeskinahmet@gmail.com. 
zed within Turkish culture from ancient times to present day. First of all, the sayings and behaviors used as a way of greeting and saying goodbye are primarily emphasized to this extent. Then, the information conveyed from researches working on Turkish language and culture is considered. In the continuation of the study, the words and structures were used referring greeting and saying goodbye among Turkish tribes living in various parts of Turkish world are detected, divided into certain groups considering the origin of words, and then evaluated. In the light of references of these data, an inference about how the greeting and saying good bye in Turkish culture is performed was done. In order to compare the words and structures used for greeting and saying goodbye among the Turkish tribes, a table, which include the list of words used for greeting, is attached to the end of the study.

Keywords: Turkish culture, Turkish dialects, daily life, communication, "greeting", "saying goodbye".

\section{Giriş}

Her toplumun, gündelik yaşamın çeşitli alanlarında belirli durumlara ve ihtiyaçlara bağlı olarak başvurduğu farklı iletişim biçimleri bulunmaktadır ve bu nedenle de kültürel değişim, dönüşüm ve farklılıkların izlenebildiği başlıca alanlardan biri de iletişim türleridir. Gerçekleştirildikleri bağlamlarda paylaşımcıları tarafından kolayca anlaşılabilir nitelikteki iletişim biçimleri tekrar edilme sıklığı nedeniyle gündelik yaşamın rutin davranışları hâline dönüşmüştür. Hitap şekilleri, nezaket sözleri, iyi ve kötü dilek sözleri ile selamlaşma ve vedalaşma sözleri de toplumların kültürel özelliklerine göre şekillenen, bu dilsel ifadeleri üretip paylaşanlar tarafından kolayca anlaşılabilen, dil ve davranış esaslı iletişim türleri ve mesaj sistemleridir. Bu anlamda, bir toplum ve kültürün geçmişine bağlı olarak sosyokültürel yapı içerisinde şekillenen konuşma tür, biçim ve söylemleri de iletişimin başlıca araçlarından biri olan dil aracılığgyla aktarılmaktadır. Dil ve kültür arasındaki ilişkiler bütününün çeşitli yansımaları olan, gündelik (rutin) iletişimde kullanılan bu eylem ve söylem biçimleri sosyal ve kültürel açıdan insan yaşamında tuttuğu işlevsel yere bağlı olarak toplumsal, dinî ve ahlaki şartlara ve değerlere göre farklı biçimlerde gerçekleştirilmekle birlikte, her dönem ve coğrafyada, varlığını geçmişten günümüze sürdürmüştür.

Toplumu oluşturan bireylerin birbirleriyle karşılaşma, karşılıklı hâl hatır sorma ve vedalaşma sırasında hangi ifadelere ya da davranış kalıplarına başvurdukları, o toplumun sosyokültürel özellikleri hakkında bilgi verebilmektedir. Bu bakımdan günlük hayatta gerçekleştirilen iletişim biçimleri belirli kurallara göre oluşturulan, içinde kullanıldığ1 grubun sosyokültürel özelliklerini yansıtan davranışlar ve bunların dil aracılığıyla dışavurumları olarak kültür araştırmalarının bir parçası olarak değerlendirilmektedir. Her kültürün kendi özellikleri doğrultusunda, kültüre özgü biçimde şekillenen iletişim bi- 
çimlerinin ve bunlar arasında yer alan selamlaşma ve vedalaşma biçimlerinin bu nedenle dil ve kültür bilimciler tarafindan, dil bilimi ve halk biliminin inceleme alanı içerisinde değerlendirilerek söz konusu alanlardaki çalışmalara konu edildiği görülmektedir. ${ }^{1}$ Böylece, kendisi de estetik bir iletişim biçimi olan halk kültürünün bir kolunu da, gündelik yaşamdaki iletişimi sağlayan selamlaşma ve vedalaşma eylem ve söylemlerinin oluşturduğunu belirtmek mümkündür. Halk bilimi, antropoloji ve dil biliminin ortaklaşa inceleme alanına giren selamlaşma ve vedalaşma olgusunun Türk kültür tarihindeki görünümlerinin araştırılması da bu anlamda, Türk dili ve kültürü çalışmalarında dikkat çeken bir konu olarak karşımıza durmaktadır.

Karşılaşma sırasında iletişimin başlatılmasında selamlaşma, diyalog sürecinin ve bu anlamda selamlaşma ile başlayan iletişimin sonlandırılmasında ise vedalaşma işlevinde kullanılan ifade ve davranışlara başvurulmaktadır. Karşılaşmaktan kaynaklanan duyguların bildiriminin gerçekleştirildiği selamlaşma ile diyalog sürecinin olumlu ya da olumsuz sonuçlandığını yansıtma ve tekrar görüşme zamanını belirtme gibi özellikleri bulunan vedalaşma sözcüklerinin bu temel yapı ve işlevleri, bütün dünya kültürleri ve dilleri için geçerlilik taşımaktadır (Sagınbayeva 2013: 2). Bu doğrultuda Selamlaşma olgusunun Türk kültüründe en geniş biçimiyle; (1) selamlaşma sürecine dönük iletişimin başlatılması, (2) karşılıklı hâl hatır sorma ve (3) vedalaşma şeklinde 3 ana aşamada gerçekleştirilen bir süreç olarak değerlendirilmesi mümkündür. Dolayısıyla da selamlaşma ve vedalaşma, iletişimin başlatılmasını ve sonlandırılmasını sağlayan, bu yönüyle "selamlaşma" üst başlığı altında değerlendirilmesi mümkün olan iki benzer iletişim biçimi ve dolayısıyla da bir bütünün iki parçası gibidir. Bu düşünceden hareketle, çalışmadaki değerlendirmelerden kaynaklanabilecek olası bir kavram kargaşasını da önlemek için, "selamlaşma" ve "selamlaşmak" ifadelerinin hem "selamlaşma" eylemini hem de selamlaşmanın bir parçası olarak değerlendirilebilecek olan "vedalaşma" eylemini karşılar biçimde, kapsayıcı bir üst kavram olarak kullanıldığını belirtmek yerinde olacaktır. "Vedalaşma" ve "vedalaşmak" ifadeleri ise çalışmanın bütününde, kendi anlamlarını karşılayacak biçimde kullanılmıştır.

Bu çalışmada, Türk kültüründe selamlaşma konusu başlangıçtan günümüze kadar, elimizde bulunan somut kaynaklar ve onlar aracılığılla ulaşılabilen veriler üzerinden belirlenebilen temel görünümleriyle ve genel hatlarıyla ele alınmıştır. Bu doğrultuda öncelikle, günümüzde Türkiye'de selamlaşmada kullanılan sözcük, ifade ve davranışlar hakkında genel bir değerlendirme ya-

1 Kültürün yansımaları olarak günlük hayattaki iletişim biçimlerinin ve bu iletişimlerin gerçekleştirilmesinde başlıca araç olarak kullanılan dilin sosyokültürel düzlemde incelenmesi, halk biliminin ve dil biliminin başlıca çalışma alanlarından biridir. Dil, kültür ve insan ilişkileri bağlamında günlük iletişimin rutinleri, kalıp davranışlar, ifadeler ve özellikle selamlaşma ve vedalaşma biçimlerinin sosyokültürel nitelikleri, bunların sosyodil bilimi ve halk bilimiyle ilişkileri hakkında bk. Coulmas 1979: 239-266; Toelken 1996: 9; Dundes 1965: 2-3; Dundes 1966: 238; Duranti, 1992: 658-659; Duranti 1997: 63-97; Erol 2007: 4-285; Karadayı 2008: 89-107. 
pılmıştır. Ardından, Türk kültür tarihinde selamlaşma konusunda çeşitli araştırmacıların ortaya koyduğu bilgi ve görüşler aktarılmıştır. Çalışmanın devamında, Türk dilinde selamlaşma maksadıyla kullanılan sözcük ve ifadeler, Türk lehçeleri ve kültürel alanları üzerinde hazırlanmış olan, başta sözlük çalışmaları olmak üzere, çeşitli araştırmaların karşılaştırmalı olarak incelenmesi yoluyla tespit edilerek belirli gruplar altında değerlendirilmiştir. Bu gruplar altında yapılan değerlendirmeler üzerinden konu hakkında ulaşılan sonuçlar paylaşılmıştır. Türk kültür tarihinde selamlaşma konusunun Türk boyları arasındaki art ve eş zamanlı durumunun karşılaştırmalı olarak izlenebilmesi için çalışmanın sonuna, selamlaşma ile ilgili kullanılan sözcük ve ifadeleri içeren bir tablo eklenmiştir. Böylece, Türk kültür tarihinde selamlaşma konusu bütüncül bir şekilde değerlendirilmeye çalışılmıştır.

\section{Türk Kültür Tarihinde ve Günümüzde Selamlaşma ve Vedalaşma}

Farklı milletlerin selamlaşma eylemlerinde, karşılaşma esnasında iyi niyet, ayrılma esnasında ise ilahî esenlik dileyen sözlerin ağırlıklı olarak kullanıldığı görülmektedir. Bu durum, tarihin en erken dönemlerinden itibaren maddi (düşmanlık, soygun), manevi tehlike (kötü ruhlar) ve bilinmezliklerle mücadele etmeye yönelik olarak insanların temel güvenlik gereksinimlerini karşılamaya dönük işlevsel tutumlarından kaynaklanmış olmalıdır. Bu doğrultuda selamlaşma eylemi ve bu eyleme bağlı davranış kalıpları, söylemler ve sözcükler, tarihî süreçte farklı kültürlerde insanların birbirlerine "zarar vermeme" ve birbirlerinden "zarar görmeme" anlayışı temelinde gelişmiş olduğu belirtilebilir. Bu anlamda selamlaşma, insanlık tarihinin en eski dönemlerinden beri "barış" belirtisi taşıyan bir iletişim ve davranış biçimi olarak kabul görmüş, bu temelde ortaya çıkmış ve gelişmiştir. Her toplum ve kültür, kendi iç dinamiklerine ve ihtiyaçlarına göre belirlediği selamlaşma davranışlarını bir sisteme bağlamış ve bunu dil aracılığıyla sözcüklere dökerek kendilerine özgü selamlaşma biçimlerini oluşturmuştur. Belirli bir işlevsel temel üzerinde başlayıp devam eden bu eylemler, bunlara bağlı olarak yaratılan davranış kalıpları, sözcükler ve söylemler, tarihî süreç içerisinde belirli değişim ve dönüşümlere uğrasalar da varlıklarını sürdürerek günümüze kadar ulaşmışlardır.

Türk kültür tarihinde selamlaşma işleviyle kullanılan, beden dili ve davranış biçimleri arasındaki başlıca selamlaşma yöntemlerini ise el sıkışmak, başın öne doğru eğilmesiyle saygı gösterisinde bulunmak, el sallamak, elin baş tarafina götürülmesi, sağ eli göğsün üzerine götürmek, sarılmak, el sıkışarak veya omuzları birleştirerek sarılmak, gülümsemek/göz kırpmak, başı hafifçe öne doğru eğmek ve el öpmek şeklinde sıralamak mümkündür. Bu doğrultuda Türk kültüründe davranış kaynaklı selamlaşma türlerinin, yoğun olarak "el”, "baş" ve "bağır" bölgeleri üzerinden gerçekleştirildiği görülmektedir. Selamlaşmaya dönük olarak "öpmek" eyleminin ise Türk kültürüne, görece olarak, 
daha sonraki dönemlerde eklemlendiğini ifade etmek mümkündür. Bunların dışında kalan ve çeşitli grupların kendi aralarında kullandıkları farklı selamlaşma ve vedalaşma yöntemlerinin de olabileceği kuşkusuzdur. Bunlar, davranış kaynaklı iletişim yöntemleri olarak beden folklorunun kapsamına giren ve ifade ettikleri anlamın toplumdan topluma değişmesinin mümkün olabileceği davranış biçimleridir.

Türkiye'de, günümüzde yaygın biçimde kullanılan alış1lagelmiş selamlaşma sözcük ve ifadelerini ise; merhaba, selamünaleyküm, selam(lar), günaydın(lar), iyi sabahlar/hayırl sabahlar, iyi günler/hayırlı günler, iyi akşamlar/hayırlı akşamlar, iyi geceler/hayırlı geceler, iyi yolculuklar, hoş geldiniz, Allah'a ısmarladık/Allah'a emanet ol, hoşça kal(in), esen kal(in)/esenlikler (dilerim), görüşmek üzere/görüşürüz/eyvallah, kendine iyi bak, güle güle ve elveda şeklinde sıralamak mümkündür. Selamlaşmak için kullanılan bu ifadeler, kültürün ve iletişimin sözel boyutuyla ve dolayisıyla dil aracılığıyla temsil edildiği örneklerdir. Söz konusu selamlaşma sözcük ve ifadelerinden, iyi sözcüğünü içeren ifadelerin good morning, have a good day, have a nice sleep (...); hoş geldiniz sözcügünün wellcome; görüşmek üzere/görüşürüz, hoşça kal sözcüklerinin see you, see you later; kendine iyi bak sözcügünün take care, take care of you; güle güle (git) sözcügününse good bye şeklindeki yabanc1 kalıplarla olan benzerliği dikkati çekmektedir. Selamünaleyküm, merhaba, Allah'a ısmarladik/Allah'a emanet ol ifadelerinin ve hayırl ibaresini taşıyan kullanımların ise Türklerin İslamiyet ile tanışmalarından sonraki dönemlerde, Arapçanın etkisiyle yaygınlık kazandığı açıktır. Selam şeklindeki kısa ifadeyi ise, Arapça kaynaklı selamünaleyküm ifadesinin Batı dillerinden kaynaklı, özellikle İngilizce $h i$, hello sözcüklerinin senteziyle şekillenen melez bir ifade olarak değerlendirmek yanlış olmayacaktır.

$\mathrm{Bu}$ benzerliklerin, insanların dünyayı algılayış biçimlerindeki ortaklıkların ya da farklı toplumlar arasındaki kültürel etkileşimin "doğal" ya da "yapay" bir sonucu olarak ortaya çıktığı düşünülebilir. Bu durumun, dünya dillerindeki selamlaşma sözcüklerinde genel olarak iyi dilek ifadelerinin ön plana çıkartılmasıyla da ilişkilendirilebilmesi mümkündür. Bu sözcüklerin mutlak surette söz konusu dillerden etkilenilerek ve belirtilen şekilde oluştuğunun söylenemeyeceği gibi, bunların bütünüyle Türk dili ve kültürü kaynaklı kullanımlar olduğunu iddia etmek de doğru bir çıkarım olmayacaktır. Bu durumda, uzun ve köklü bir geçmişe sahip olan Türklerin tarihî süreçte kendilerine özgü selamlaşma biçimlerinin olup olmadığ ve selamlaşıp vedalaşırken hangi ifade kalıplarını kullanmış oldukları sorusu akla gelmektedir. Bu doğrultuda, Türklerin tarihin daha eski dönemlerinde selamlaşma eylemlerini nasıl gerçekleştirdikleri hakkında bazı değerlendirmelerin yapılması ve Türk kültür tarihinde selamlaşmada kullanılan sözcük ve ifadelerin incelenmesi gerekmektedir. 
Faruk Sümer, Türklerin aile hayatından ve kullandıkları saygı ifadelerinden bahsederken, Türklerin tarihte nasıl selamlaştıkları konusuna da değinmiştir. Sümer konuyla ilgili olarak, Dede Korkut Kitabi'nda geçen Baş indürüp selam virdiler (Ergin 2004: 120), Delü ozan geldi, baş indürdi, bağır basdl, selam virdi (Ergin 2004: 144), El kavuşturup ol yigide selam virgil (Ergin 2004: 227), Big baba hatun ana esen kalın (Ergin 2004: 228) örneklerini aktarmıştır. Daha sonra; Dedem Korkut öteden berü geldi. Baş indürdi, bağır bastl, ă̆ız dilden görklü selam virdi (Ergin 2004: 125) örneği üzerinden, "baş indirip bağır basmak" şeklinde bir selam verme biçiminden söz eden Sümer, bu selam verme biçiminin millî bir vasıf taşıyıp taşımadığının ise henüz bilinmediğini vurgulamıştır. ${ }^{2}$ Sümer' in konu ile ilgili aktardığı bilgiler arasında, İdil boyu Bulgarlarının kalpaklarını çıkarıp koltuk altlarına koyduktan sonra başları ile hükümdarlarına selam vermesi, Melik Şah'ın amcasına selam verirken atından inerek külahını başından çıkarması gibi bilgiler de yer almaktadır (Sümer 1980: 405-406).

Bahaeddin Ögel'e göre ise Türklerde selam, "baş eğme ve diz çökme” ile özetlenebilir. ${ }^{3} \mathrm{Bu}$ doğrultuda Göktürk Yazıtları'nda geçen başlıya baş eğdirmiş, dizliye diz çöktürmüs (Ergin 2006: 9) ifadesini ve Dede Korkut Kitabı'nda geçen selamlaşma örneklerini aktaran Ögel, Türklerin daha çok Tanrı'ya ve hükümdarlara selam vermek ve saygı gösterisinde bulunmak amaciyla secde ettiklerini, Cengiz Han'ın güneşe "sağ dizi üzerinde çökerek" selam verdiğini ve "el sunma”nın da bir selamlaşma biçimi olduğunu aktarmaktadır (Ögel 2001: 551-552). Eski T'ang Tarihi'nde de bir Türk kağanı olan Eliğ Kağan'ın yanındaki beylerin, "atlarından inip diz çökerek selam verdikleri” aktarılmaktadır (Togan 2006: 11). Ögel'in verdiği bilgiler arasında dikkati çeken bir husus da, karşılaşma sırasında söylenen iyi dileklerin de Türkler arasında bir selamlaşma biçimi olarak kullanılmasıdır (Ögel 2001: 552). Böylece, Türklerin tarihî süreçte birbirlerine bildirdikleri iyi dilek sözleri aracıllğıyla da selamlaştıkları anlaşılmaktadır ki bu, selamlaşma ve alkışlar arasındaki ilişkinin de bir yansımasidır.

Yine Bahaeddin Ögel'in Çinli seyyah ve elçi Wang Yent'ê'nin seyahatnamesinden aktardıklarından, Uygur Kağanı'nın Çin elçisini kabulü sırasında hazır bulundurulan bir taştan çıkan ritme uygun selam düzeni alındığını, başta kağan olmak üzere törende bulunanların önce doğudan başlamak üzere gerçekleştirilen özel bir selamlama yönteminin varlığı anlaşılmaktadır (Ögel 2000: 125). Bunlar, Türklerin erken dönemlerde ne şekilde selamlaştıkla-

2 Bunlara ek olarak; Dede Korkut Kitabı'nda kahramanların birbirleriyle karșılaștıkları sırada aktarılan manzum parçaların önemli bir kısmının, "kahramanların kendilerini tanıtması" işlevini de taşıdığı, kahramanın karşısındakiyle iletişimini kuran bu parçaların, "tanıtma" ve "tanınma" maksadıyla kullanılan kalıp ifadeler biçiminde bir tür "selamlaşma" işlevini yerine getirdiklerini belirtmek gerekmektedir.

3 Bu doğrultuda; Moğolca egülen(ü) çilagun, böküy-, böküylge- mörgülce- ve mökülce- sözcüklerinin "bükülmek, eğilmek, secde etmek" anlamlarının yanında "selam vermek, selamlaşmak" anlamlarına da gelmesi dikkat çekicidir (Krş. Lessing 2003a: 203, 478, 853, 858). 
rı hakkında ipuçları vermesi bakımından önem taşımaktadır. Aynı zamanda, bu selamlaşma biçimlerinin önemli bir kısmının daha çok devlet işlerinde ve resmî ortamlarda kullanılan selamlaşma biçimleri olduğunu, daha az bir kısmının ise günlük hayatta kullanılan selamlaşma sözcüklerinden ziyade çeşitli davranış biçimlerini temsil ettiğini vurgulamak gerekmektedir. Yine bu örnekler, devlet düzeni içerisinde kendine özgü selamlama sistemleri geliştirdiği görülen Türklerin, günlük yaşamdaki iletişimi sağlamak için de kendilerine özgü selamlaşma yöntemlerine sahip olabileceğini düşündürmesi bakımından da önem taşımaktadır.

Bu doğrultuda; Kâşgarlı Mahmud'un 1072 yılında kaleme aldığı, Türklerin toplum hayatındaki ve günlük yaşamındaki davranışları hakkında bilgi edindiğimiz önemli kaynaklardan biri olan Dîvânu Lugati't-Türk adlı eserin son derece önemli olduğunu belirtmek gerekir. Eserde boy maddesi açıklanırken, birbirlerini tanımayan iki insanın karşılaştıkları zaman önce selamlaştıkları, sonra birbirlerine "hangi kabiledensin" anlamına gelen boy kim(?) sorusunu sordukları, bundan sonra ya konuşmaya devam ettikleri ya da durmaksızın ayrıldıkları, böylelikle birisinin diğerinin kabilesini tanımış olduğu aktarılmaktadır (Atalay 1998: 141; Akalın 2008: 114). Bu durumda, Türklerin o dönemlerde, birbirleriyle karşılaştıklarında ilk olarak selamlaştıkları, iki insan arasındaki iletişimin de bu şekilde başlatıldığı anlaşılmaktadır. Ayrıca, selamlaşma sırasında kimsin(?) veya nasilsın(?) anlamında, boy kim(?) şeklinde, kimlerdensin anlamına gelen bir ifadenin kullanıldığı da dikkati çekmektedir. Bunu, günümüzde de kullanılan kimlerdensin ifadesinin (Akalın 2008: 114), selamlaşmanın yerini tutan, tanıma ve tanınmayı sağlayan bir kalıp ifade olarak düşünmek mümkündür. Bu, Türklerin eski çağlarda selamlaşırken, hâl hatır sorarken, kişilerin bireysel kimliklerinden ziyade onların hangi aile birliğine bağlı olduklarını, hangi boy veya topluluğa mensup olduklarını üzerinden öğrenmeye çalıştığını göstermesi bakımından önemlidir.

Bütün bu özellikleriyle boy esasına dayalı selamlaşma ve boy sözcüğü doğrultusunda sağlanan tanıma ve tanınma bilgisi, Türk kültür tarihinde selamlaşma konusunda ulaşılabilen en eski veri olarak ön plana çıkmaktadır. Türklerin eski çağlarda selamlaşırken veya hâl hatır sorarlarken, kişilerin bireysel kimliklerinden ziyade hangi boy veya topluluğa mensup olduklarını ön plana çıarmaları, söz konusu dönemde fertlerin günlük yaşantısında içinde yaşadığı boya bağlı kalmalarıyla ve kişilerin birbirlerini tanımasının, mensubu oldukları boylar üzerinden gerçekleştirmeleriyle ilgili olmalıdır (Genç 1997: 84). Boy kim(?) şeklindeki selamlaşma biçiminin, Türkler tarafından eski çağlarda kullanılmış bir ifade olduğu açıktır. Ancak, Türklerin boya bağ11 olarak gerçekleştirdikleri bu sorgularının, selamlaşma biçimi olarak hangi yaygınlıkta ve hangi zaman aralıklarında kullanıldığı hakkında kesin yargılara varmak mümkün değildir. Ayrıca, Türklerin erken dönemlerde selamlaşma 
konusundaki tutumları hakkında, ne yazık ki, boy esasına dayalı bu selamlaşma türü dışında pek fazla bilgi bulunmamaktadır.

Türklerin tarih boyunca kullanmış oldukları çeşitli selamlaşma biçimlerinin günümüzde de çeşitli biçimlerde, Türk dünyasının çeşitli bölgelerinde yaşayan Türk boyları arasında hangi oranda, benzer ya da farklı biçimlerde kullanılıp kullanılmadığının belirlenmesi de konuyla ilgili yapılması gereken araştırmaların diğer bir yönünü oluşturmaktadır. Bu kapsamda belirtilebilir ki; Türk kültür tarihi üzerinde yapılan çalışmalar aracılığıyla, Türklerin en erken dönemlerden itibaren selamlaşma ve vedalaşma hususunda hangi sözcük ve ifadeleri, ne tür tutum ve davranışları benimsedikleri konusunun daha ayrıntılı bir şekilde değerlendirilmesi, karşılaştırmalı araştırmalar gerçekleştirilmeden mümkün görünmemektedir. Türk dili ve kültürü sahasında gerçekleştirilmiş olan çalışmalar üzerinden, Türklerin kullanmış oldukları selamlaşma ifadeleri hakkında kısıtlı bilgiye sahip olunabilmekle birlikte, Türklerin selamlaşma tutumları ve selamlaşmada kullandıkları sözcük ve ifadelerin tarihî süreçteki gelişimleri hakkında ayrıntılı bilgiye ulaşmak şimdilik pek mümkün değildir. Konu bu yönüyle, ayrıntılı biçimde ele alınabilecek niteliktedir. Ancak, bu çalışmanın gerektirdiği sınırlılığa bağlı olarak çalışmanın bundan sonraki kısmında, Türk kültürü ve lehçeleri alanlarında yapılmış çeşitli araştırmalarda, Türk lehçelerindeki selamlaşma ve vedalaşma ifadeleriyle ilgili yer alan bilgi, açıklama ve kayıtlar aracılığıyla, Türk kültüründe selamlaşma ve vedalaşma konusu incelenecektir.

\section{Türk Lehçelerinde Selamlaşma İşlevinde Kullanılan Sözcük ve İfa- deler}

Çalışmanın bu kısmında, Türklerin tarih boyunca, selamlaşma süreçlerinde kullandıkları sözcük ve ifadeler, Türk lehçelerindeki kullanımları esas al1narak karşılaştırmalı bir şekilde incelenmiştir. Bu doğrultuda, Türk boylarının dil ve kültürü üzerine hazırlanan, birçoğu sözlük niteliği taşıyan kaynaklar titizlikle taranmış, bu kaynaklarda selamlaşma işlevinde kullanıldığ 1 tespit edilen sözcük ve ifadeler, kökenleri dikkate alınarak belirli gruplar hâlinde tasnif edilerek kullanım yoğunlukları ve birbirleriyle olan ilişkileri doğrultusunda incelenmiştir. İlk gurupta Türkçe ve Moğolca kökenli, ikinci gurupta ise Arapça ve Farsça kökenli sözcük ve ifadeler, çeşitli alt gruplara ayrılarak incelenmiştir. Üçüncü ve son grupta ise, ilk iki grupta incelenen unsurların dışında kalan sözcük ve ifadeler değerlendirilmiştir.

\subsection{Türkçe ve Moğolca Sözcük ve İfadeler}

\subsubsection{Esen, Aman ve Să̆/Sav}

Türkçede selamlaşmak için yaygın biçimde kullanıldığ 1 görülen ifadeler arasında, aman, esen ve sağ/sav sözcükleri ile bu sözcüklerden türetilen çeşitli 
ifadelerin önemli bir yer tuttuğu görülmektedir. Bu üç sözcügün Türk boylar1nın lehçelerinde çoğu zaman çeşitli birleşimler hâlinde, bazen de tek başlarına kullanıldığı, bu kullanımlarda sabit bir şekilde "sağlık, salimlik, iyilik, rahatlık" anlamlarının ön plana çıkartıldığ 1 dikkati çekmektedir. Dolayısıyla bu üç sözcügüü ayrı ayrı değil, birbirleriyle olan yakın ilişkileri kapsamında ve bir arada değerlendirilmesi yerinde olacaktır.

Dîvânu Lugâti 't-Türk'te üç kez geçen (Atalay 1991b: 194) esen sözcüğünün anlamı, Kâşgarlı Mahmud tarafından; "sağ, salim" şeklinde verilmiş ayrıca; “'esen müsen? =sağ misin?', bu kelime 'selâmet' manasinda dahi kullanılır" biçiminde açıklanmıştır (Atalay 1991a: 77). Yine, Dîvânu Lugâti 't-Türk'te üç kez geçen esenle- fiilinin anlamı "selamla-" olarak verilmiş, esenledi maddesi "selamladı", bu maddenin altındaki esenler sözcüğü de "esenle-" şeklinde açılanmıştır (Atalay 1991a: 308; Atalay 1991b: 194). Bu çerçevede "esenle-“ fiilinin "mutluluk dilemek, sağlıklı ve sevinçli olmasını istemek, yola çıkanı uğurlamak" anlamlarını taşıdığ görülmektedir. Gerard Clauson da etimolojik sözlügünde esenle-, esenleş-, esengüle maddeleri altında "birinin hâl hatırını ve sağlığını sor-, birini selamla-, bir veda ifadesi, iyi dilek" açıklamalarında bulunmuş ve sözcügün Osmanlı döneminde kullanılmaya devam ettiği bilgisini aktarmıştır (Clauson 1972: 249, 250).

Günümüzde, Türkiye Türkçesinde unutulmaya yüz tutmuş hâlde bulunan ve kullanımı; esenlik(ler) dilerim ve esen kal( $\mathrm{ln}$ ) ifadeleriyle sınırlı olan esen sözcügünnden türeyen çeşitli ifadelerin, Türk boyları arasında yaygın olarak kullanıldığı görülmektedir. Buna göre esen sözcüğü Altay Türkçesinde "1. Esen, sağlık, afiyet, sağliklı, 2. (Selamlaşma sözü) merhaba, esenlikle, sağl1kla." şeklindedir. Ezendeş "selam", ezendeş- "selamlaş-", ezendik "sağlık, esenlik", ezendik bolzın "selam olsun" anlamlarına gelmektedir. Aynı kökten türeyen ezen bolzın ise "güle güle" demektir. (Naskali-Duranl1 1999: 85-86). Hakas Türkçesinde is "merhaba", izen pir- "selam ver-", izenne- "selamlamak, selam vermek", izenner "selam, merhaba", izennes- "selamlaşmak, selam vermek", izen mindi "merhaba", izen polzın "yaşasın" anlamlarına gelmektedir (Naskali 2007: 233-234). Hakas Türkçesinde izen sözcüğünün "sağlıkl1, sağlam, hayatta" anlamlarının yanında "selam" anlamı da bulunmakta, izen pir"selam vermek, merhaba, selam" anlamına gelmektedir (Arıkoğlu 2005: 231).

Kazak Türkçesinde esendik sözcügü "esenlik, sağllk", esendes- "selam ver-, selamlaş-, merhabalaş-, vedalaş-" anlamlarına gelmektedir (Koç 2003: 144). Aman, aman-esen, esen-aman, aman-sav sözcükleri ise Kazak Türkçesinde "săg, salim, esen"; amandas- "selamlaş-" anlamlarına gelmektedir (Baynizarov 2007: 278). Aman-savllk bilis- ve esen savllk suras- ise "selamlaş-, merhabalaş-" anlamındadır (Baynizarov 2007: 550, 647). Kırgız Türkçesinde esendeş- "selamlaş-, karşl1ıklıca sihhatlerini soruştur-" anlamındadır 
(Yudahin 1998: 340). Aman-esen bartp kel(iñiz), aman-esen cetip al(ıñız), aman barı, aman kel(iñiz) "iyi yolculuklar, yolunuz açık olsun" anlamına gelmektedir (Sagınbayeva 2013: 3). Özbek Türkçesinde esan "sağ, salim", esanlik, esan-amanlik "sağ, salim olma", esanlaş- "selamlaş-", aman "sağ, selamet, esen olma", amanlaş- "birbirine hâl hatır sor-, selamlaş-, vedalaş-" anlamlarına gelmektedir (Ma'rufov 1981a: 536-537; Ma'rufov 1981b: 454).

Tatar Türkçesinde de ayrılırken savbul karşl1ıklı esenlik, sağlık dileyerek vedalaşma işleviyle kullanılmakta ve savbullaş- fiili "selamlaşmak" ve "vedalaşmak" anlamına gelmektedir (Ganiyev 1997: 267; Öner 2009: 230) Tatar Türkçesinde savbısız(?) "merhaba, nasılsınız(?)" anlamlarında, savbul(ıgız) "hoşça kal(ın), Allah'a 1smarladık" anlamında kullanılmaktadır (Ganiyev 1997: 267). Tatar Türkçesinde "sağ, diri, selamet, sağlıklı, esen" anlamındaki isen sözcügü ile birlikte isen(lik)-sav(lik) ve isen-imin sözcükleri de "sağlık, salimlik, esenlik" anlamında, bundan türetilen isenleş- sözcügü selamlaşmada "hâl hatır soruşmak" anlamında, isenmi(siz)(?) "merhaba, nasılsınız(?)", isen bul((ğgız) sözcügü de "hoşça kalınız" anlamına gelecek şekilde selamlaşmada ve vedalaşmada kullanılmaktadır (Ganiyev 1997: 114; Öner 2009: 121). Türkmen Türkçesinde de sag bol sözcüğünün, selamlaşmak ve vedalaşmak için kullanıldığ1 görülmektedir (Hamzaeva 1962: 569). Sag sözcüğünün sag-salim, sag-gurgun, sag-salamat ikileme biçimlerindeki kullanımları da Türkmen Türkçesinde, "sağlık, salimlik, esenlik" bildirmektedir (Tekin vd. 1995: 551). Selamlaşmalarda kullanılan "sağ ol" anlam alanının Türkiye Türkçesinde konuşma dilinde vedalaşırken sınırlı bir alanda, sağlıcakla kal(ın)/kal(ın) sağlıcakla biçiminde kullanıldığı görülmektedir. Eski Uygur Türkçesinde ise "sağlıklı, sıhhatli, sağlam" anlamına karşılık gelen, asan, asangü, asangülük sözcüklerinden türetilen esengüle- "hatır sor-" biçiminde bir kelime bulunmaktadır ki bunlar aynı kökenden gelmektedir (Caferoğlu 1968: 21, 76). Nitekim, Yeni Uygur Türkçesinde de esen, esen-aman(lik) ve esenleş- sözcükleri "sağlık, salimlik, hâl hatır sor-, selamlaş-" anlamlarını taşımaktadır (Necipoviç 1995: 126).

Bütün bu veriler, esen, aman ve sağ/sav sözcüklerinden türetilen çeşitli ifadelerin Türk dilinde ve kültüründe hem karşılaşma hem de ayrılma s1rasında "selam" ve "veda" anlamlarında kullanıldığını göstermektedir. Bazı lehçelerde sözcüğün tek başına, bazılarında ise birleşik yapılar şeklinde kullanıldığı görülmektedir. Sözcüklerin kullanımındaki değişmeyen durum ise, sözcüklerin taşıdığı "yaşam", "sağ olma" ve "esenlik" anlamlarının, bu sözcükler aracılığıyla vedalaşma sözlerinde mutlak surette kullanılmış olmasıdır. Esen sözcüğü temel alınarak türetilen çeşitli sözcüklerin ve bu sözcüklerin kullanımlarının kaynağında, "karşısındaki kimsenin hâlini hatırını sormak", "onun sağlığını ve mutluluğunu istemek", "kişiyi kutlu kılmak" gibi temel 
düşüncelerin yer aldığını söylemek mümkündür. ${ }^{4}$ Arapça selamet sözcüğünün Türkçesi olarak düşünülebilecek olan bu sözcügün hem Türkçenin ve Türklügün en eski dönemlerinde hem de Osmanlı döneminde ve Türkçesinde yaygın olarak kullanıldığı anlaşılmaktadır. Bu doğrultuda, Türkçede kullanılan esen sözcügünden türetilen çeşitli sözcükleri, Arapça kökenli selam ve veda sözcüklerinden türetilen çeşitli selam ve veda ifadelerinin Türk dili ve kültüründeki arkaik karşılıkları olarak belirlemek yerinde olacaktır. ${ }^{5}$

\subsubsection{Mendü, Bayar ve Colga}

Türk boylarının selamlaşmak için kullandıkları ifadeler arasında, Moğolca kökenli mendü, bayar ve colga sözcüklerinden türetilen çeşitli sözcüklerin de önemli bir yer tuttukları görülmektedir. Moğolaca mendü "sağlılı ve iyi hâlde oluş" anlamlarının yanında, hatır sormak, selamlaşmak ve vedalaşmak için, "selam, merhaba, hoşça kal" anlamlarında da yaygın olarak kullanılan bir sözcüktür. Moğolcada "selam, merhaba" anlamına gelen mendü sözcüğünün Hakas Türkçesinde izen sözcüğüyle birlikte kullanıldığı görülmektedir. Hakas Türkçesinde mindi "selam, merhaba", izen mindi "sağlıkla, sağlıcakla, hoşça kal", mindile- "selam ver-, selamla-", mindiles- "selam ver-, selamlaş-" anlamlarına gelmektedir (Arıkoğlu 2005: 231, 297; Naskali 2007: 303). Burada da yine "sağlık" ve "esenlik" anlamını taşıyan bir sözcüğün hem selam hem de veda sözcüğü olarak kullanıldığ dikkati çekmektedir. ${ }^{6}$

Esen mendü ifadesi "emniyetle, sağlığ iyi olarak varmak", mendüçileifadesinin anlamı ise "selamlamak, birinin hâl ve hatırını sormak" şeklindedir (Lessing 2003a: 836, 837). Tuva Türkçesinde ise selamlaşmak için, "kutlamak, tören yapmak; selamlamak" anlamındaki bayırla- sözcügü kullanılmaktadır. Bu sözcüğün kaynağındaki Moğolca bayar sözcüğü "neşe, kut, mutluluk, selamlama, kutlama, tebrik" anlamına gelmektedir (Lessing 2003a: 122). Vedalaşmada kullanılan bayırlıg sözcügü "törensel, törenli, tören; görüşmek

4 Esen sözcügünün vedalaşma kapsamındaki kullanımının, Türklerin İslamiyet’i kabulünden sonraki yüzyıllarda da yoğun biçimde sürdüğü anlaşılmaktadır. Nitekim, erken dönem Türk inanç ve yaşam biçimleri ile İslamiyet sonrası inanç ve yaşam biçimlerinin bütünleştirildiği güzide örnekleri içeren Dede Korkut Kitabı'nda yer alan anlatmalarda Kan Turalı, evlenmek için babasının kendisine bulduğu kızı almak için canavarla mücadele etmek üzere yola çıkarken, uzun uzun vedalaşır. Bu vedalaşma, uzun manzum alkışlar şeklindedir. Kan Turalı'nın anne babasına söylediği; Big baba hatun ana esen kalun ve kırk yiğidine söylediği; her kırk işüm kırk yoldaşum/kırkunuza kurban olsun menüm başum (Ergin 2004: 186-188) ifadeleriyle biten bu manzumeleri, bir tür helalleşme, yola giderken uğurluk alma/ verme ve bu anlamda "yol/uğurlama alkışları" olarak değerlendirmek mümkündür.

5 Bu konuyu karşılaştırmak için bk. Eyüboğlu 1991: 243; Naskali-Duranlı 1999: 86; Lessing 2003a: 530.

6 Türk dünyasının kuzeyinde kalan bölgelerde yaşayan, destan metinlerine son derece önem veren ve bu metinlerin aktarım sırasında değiştirilmesi noktasında son derece "muhafazakâr" bir tutumu olan Türk boylarının, destan türündeki anlatmalarında da bu selamlaşma biçimiyle sıkça karşılaşmak mümkündür. Örneğin, Altay Türklerinin Erke-Koo Destanı'nda kahramanla karşılaşma esnasında ezen-mendi surap turd $l$ (hâl hatır sordu) şeklinde bir kullanım dikkati çekmektedir (Dilek 2007: 41). Tuva Türklerinden derlenen Hayundırıñmay Bagay-Ool destan metninde, kahramanın selamının, aas bayırın bayırlap "selamını verip" şeklinde gerçekleştiği görülmektedir (Aça 2007: 278). Yine, Hakas Türklerine ait olan Ay Huucın Destanı'nda mindi sal-, izen sal-, mindilez-, izennes-, izen-mindi gibi sözcüklerin, "selam", "selamlaşmak" ve "vedalaşmak" anlam ve işlevleriyle görülmektedir (Ergun 2010: 214, 229, 235). Örneklerini arttırmanın mümkün olduğu bu kullanımlar, Türk halk anlatmalarında selamlaşma ve vedalaşma konusunun, üzerinde ayrı bir incelemenin gerçekleştirilebileceği bir çalışma alanı olduğunu göstermektedir. 
üzere, Allah'a 1smarladık, güle güle", bayırlangıç sözcüğü "sevinçli, sevinç verici, sevindirici", bayırmıng sözcügü ise "güler yüzlü, gönül okşayıcı" anlamlarına gelmektedir (Palmbah 1955: 80). Moğolcada colga- geçişsiz fiili "karşılamak, tanışmak, kendini takdim etmek" anlamına gelmektedir. Bu fiilin geçişsiz hâli olan colgaldu ise "tanıştırmak, selamlaşmak, birbirine selam vermek" anlamına gelmektedir (Lessing 2003b: 1652).

Görüldüğü gibi, "kutluluk" ve "mutluluk" anlamlarını gelen çeşitli sözcüklerden türetilen benzer ifadelerin yine hem selam hem de veda sözleri olarak kullanılmaları söz konusudur. Nitekim çolugar sözcüğü Tuva Türkçesinde "birine selam ver-, birini selamla-" anlamına gelecek şekilde kullanılmaktadır (Palmbah 1955: 515). Çuvaş ve Tuva gibi topluluklar arasında Moğolca kökenli bu sözcüklerin yaygın olarak kullanıldığı ve söz konusu bölgede Arapça ve Farsça kökenli sözcük ve ifadelerin görece olarak çok fazla kullanılmadıkları dikkati çekmektedir. Bu durumu dil, kültür ve insan arasındaki karşılıklı etkileşimlerin inanç ve yaşam biçimleriyle olan ilişkileri kapsamında değerlendirmek mümkündür. Bu etkileşimlerde belirleyici olan başlıca etkenler, elbette ki, sosyokültürel yaşam ve inanç alanlarıdır.

\subsection{3. İyi/Edgü, Yahşi/Cakşı}

Türklerin selamlaşma sırasında kullandıkları ifadeler arasında, Türkiye Türkçesindeki iyi sözcüğüne karşılık gelen çeşitli ifadeler yer almaktadır. Buna göre, yahşi/yahşı sözcüğü Altay Türkçesinde cakşıla- "övmek, iyileştirmek", cakşılaş- "selamlaşmak, birbirine selam vermek", cakşı ba? ve cakşılar "nasilsin(?)" anlamlarına gelmektedir (Naskali-Duranl 1999: 49). Azerbaycan Türkleri selamlaşma amaçlı yahşısan? "nasılsın(?)" ve yahşı yol "güle güle" ifadelerini kullanmaktadır. Kırgız Türkçesinde de cakşısıñbı? "nasılsin(?)" anlamına gelmekte, (Yudahin 1988: 164), cakşs bar(iñzzdar) "güle güle (gidin), iyi yolculuklar", cakşs kal(iñızdar) "hoşça kal(ınız)", cakşı cat(ıñız)/ cakşı ukta(ñız)/cakşı catıp, cay tur(uñuz) "iyi geceler/uykular" anlamlarını taşımaktadır (Sagınbayeva 2013: 1-3). Özbek Türkleri de vedalaşırken yahşi baring ifadesini kullanmaktadır.

Saha Türkçesinde ise öyöö- sözcüğü "selamla-" anlamına gelmektedir (Vasiliev 1995: 234). Tuva Türkçesinde "iyi; daha iyi; merhaba" anlamlarındaki ekii sözcügüu, karşıdaki kişinin iyiliğini sorup dileme temeline dayalı kısa selamlaşma sözü olarak dikkat çekmektedir (Palmbah 1955: 578). Öyi sözcügünün Moğolcada da "selam, hey" anlamındaki bir hitap olduğu görülmektedir (Lessing 2003b: 988). Bu sözcüğün Türkçedeki edgü sözcüğü ile karşılaştırmalı olarak değerlendirilmesi durumunda ise "selamlaşma", "tanınma" ve "iyilik-sağlık" anlam alanları arasındaki ilişkiler belirginleşmektedir. 


\subsection{Arapça Kökenli Sözcük ve İfadeler: Selam, Veda, Hayr, Hoş, Razı}

Türk dilinde selamlaşmada kullanılan sözcüklerden bir kısmı ise Arapça ve Farsça selam, veda, hoş, hayr, razı gibi sözcüklerden türetilmiştir. Azerbaycan Türkçesinde salam, salamlaş-, salamat, salamatlaş-, salamaleyküm sözcüklerinin tamam1, selam ve veda ile ilgilidir (Altaylı 1994b: 1011-1012). Çuvaş Türkçesinde salam "selam", alikkem "selam formülü" (Paasonen 1950: 3, 117), Gagauz Türkçesinde selem "selam, selemet "selamet, barış, hürriyet", selemleşmee "selamlaş-", selemlemee, sölemlemee "selamla-, kutla-, tebrik et-" hayr olsun "iyi akşamlar" anlamlarına gelmektedir (Baskakov 1991: 116, 212, 224). Kazak Türkçesinde selem, selemles- ifadeleri, selamlaşmada yaygın olarak kullanılan başlıca sözcükler arasındadır (Baynizarov 2007: 278, 756).

Hoş sözcügünden türetilmiş olan koştasu, koş aytısu, koş bol sözcükleri de Kazak Türkçesinde hem selamlaşmayı hem de vedalaşmayı ifade eden selamlaşma ifadeleridir (Baynizarov 2007: 278, 756). Kırgız Türkçesinde kayır sözcüğü "güle güle" anlamına gelmektedir ve Kırgız Türkçesinde vedalaşma sırasında söylenen koş bol(uñuzdar) ifadesi "hoşça kal(1nız)" demektir. Salamatta bar(ıñıdar) "güle güle git(iniz)", salam ayt(iñz) ise "selam söyle(yiniz)" anlamına gelir (Sagınbayeva 2013: 1-3). Tatar Türkçesinde selamet "sağ, diri”, selametlik "sağlık, dirilik,", selam, selam bir-, selamle- sözcükleri "selamlaş-" anlamına gelmektedir (Ganiyev 1997: 284-285; Öner 2009: 232). Huş ve huşıgız sözcükleri "hoşça kalın", huşlaş- ve huşlaşu da "karşıllıklı veda et-" demektir (Ganiyev 1997: 380).

Özbek Türkçesinde de selam, selamla-, selamlaş-, selamaleyküm, selam-alik, selam aliklaş-, selamlaşiş, selamlaşiş- sözcükleri "selam alıp ver-, selamlaş-" anlamlarında kullanılmaktadır (Ma'rufov 1981a: 15-16). Özbek Türkçesindeki "hoş geldin(iz), hoş kal(in)" anlamlarına gelen huşlaş- fiili de karşılama ve uğurlama sırasında kullanılan bir sözcüktür. Yine huş kelibsiz "hoş geldiniz", huş endi, huş kaling "hoşça kal(ın)", hayrlaş-, vidalaş- ve razılaş- "vedalaş-" anlamlarına gelmektedir (Ma'rufov 1981a: 177, 342; Ma'rufov 1981b: 343, 626). Türkmen Türkçesinde salam ve salavmaleykim, essalavmaleykim, heliksalam, valeykisselam yaygın olarak kullanılan selamlaşma sözcüklerdir (Tekin vd. 1995: 206, 343, 556, 562). Uygur Türkçesinde salam, essilam, essilamualeyküm sözcükleri selamlaşmada; elvida, vidalaş- ve razi, razilaş-, razilaşiş ise ayrılırken vedalaşmada kullanılmaktadır (Necipoviç 1995: 112, 117, 331, 338, 453). Türkmen Türkçesinde hoşlaşık "veda", hoşlaş- "vedalaş-, veda et-" anlamlarına gelmektedir (Tekin vd. 1995: 353). Yeni Uygur Türkçesinde heyr sözcüğü "hoşça kal, elveda", heyrleş- ve heyrleşiş "vedalaşma(k)", huş sözcügüu "hoşça kal", huş kepsiz "hoş geldiniz", huş ke- 
linlar ve huş emse "elveda, hoşça kalın", huşlaş- ve huşlaşuş da "vedalaşmak" anlamlarını taşımaktadır (Necipoviç 1995:164, 167, 169).

Görüldüğü gibi, özellikle selam sözcügüne bağl1 pek çok ifadeye ek olarak, hayr, hoş, razı sözcüklerinden türetilen çeşitli ifadeler Türk boyları arasında selamlaşma ve vedalaşma sırasında yaygın olarak kullanılmaktadır.

\subsection{Diğer Sözcük ve İfadeler}

Yukarıda aktardığımız selamlaşma sözcüklerinin dışında, Türk boyları arasında kullanılan ve selamlaşma anlamı taşıyan çeşitli ifadeler de bulunmaktadır. Kumuk Türkçesindeki "selamla-" anlamına gelen baş ur-, bork al-, ikram et- sözcükleri (Nemeth 1990: 9, 11, 27) ile Özbek Türkçesindeki, "selamlaşma, karş11ıklı selam alıp verme" anlamlarına gelen soraşış ve soraşsözcüklerini (Ma'rufov 1981a: 99) bu grupta değerlendirmek mümkündür. Ayrıca, Özbek Türklerinde, yaşlılar arasında kullanılan bequvvat misiz(?), bardam misiz(?) "iyi ve sihhatte misiniz(?)" (Dirks-Davranov 2005: 25), Tatar Türkçesinde "selamlaş-" anlamındaki tebrikle- sözcüklerini de (Shakmayev 1994: 65) bu grup içerisinde değerlendirmek yerinde olacaktır. Yine Özbek ve Yeni Uygur Türkçelerinde tazim/tezim sözcüklerinin "selam ver-, sayg1 göster-, başını eğerek selamla-" anlamları; acraş- sözcüğünün ise "veda et-" anlamı ulunmaktadır (Necipoviç 1995: 396).

Saha Türkçesinde doroobo "merhaba", bıraahaydahı "veda", bıraahaaydas- "vedalaş-" anlamlarına gelen sözcüklerdir (Vasiliev 1995: 187, 289). Türkmen Türkçesinde salyut "askerî selam", salyut ber- ve çaş ber- "selamla-, selam ver-" anlamındaki ifadelerdir (Tekin vd. 1995: 112, 558) . Kazan Tatarları ise yola çıkmakta olan kimseye ak yul sina şeklinde iyi dilek bildirmektedirler (Çetin 2007: 21) ve ak yul bilen şeklinde de kullanılan bu ifadenin "yolun açık olsun/güle güle" anlamına geldiğini belirtmek mümkündür. Kırgız Türkçesindeki vedalaşma esnasında söylenen ak col ifadesi de "iyi yolculuklar, güle güle, uğurlar olsun" demektir. Kırgız Türklerinin körüşkönçö "görüşürüz"ve ceñil barlp oor kel "kolay gidip uğurlu gel” sözcüğüyle birlikte kullandıkları, coluñ(uz)/coldoşuñ(uz) Şıdır/Kıdır bolsun "yolunuz/yoldaşınız Hızır olsun, hayırlı yolculuklar" ifadesi de yol iyesi inancının Hıdır düşüncesiyle birleşiminin vedalaşma sözcügü olarak dile yansımasıdır (Sagınbayeva 2013: 1-3). Özbek Türkleri arasında kullanılan yol bolsın (Reichl 2002: 293; Fedakâr 2006: 219) ifadesinin konuşma dilindeki bir anlamı da "yolun açık olsun"dur ve bu kullanım genellikle ak yol bolsın şeklindedir. ${ }^{7}$ Sibirya Tatarları da yolda karşılaştıkları zaman birbirlerine yol olsun diye selam verirler ki

7 Buradaki yol olsun ifadesini, esnaflar arasında kullanılan "pazar olsun" veya iyi dilek anlamında söylenen "hayırlı olsun" şeklindeki ifadelerle aynı doğrultuda düşünmek mümkündür. 
burada da yine, bir iyi dilek sözünün selamlaşmada kullanılması durumu söz konusudur (Çetin 2007: 21).

Tüm bu örnekler, yukarıda yer verdiğimiz gruplar dışında kalan, çeşitli sözcüklerin temsil ettiği ayrı bir grubu oluşturmaktadır. Buradaki "yol" ve "ak" vurgusu, "kolaylıkla gidip gelme" anlamlarının genel olarak Türk kültüründeki, özel olarak Türklerin iyi dileklerindeki, "yol” ile "aydınlık", "uğur" ve "rahatlık" arasında kurulan ilişkileri vurgulaması bakımından dikkate değerdir. Bütün bu örnekler bize, Türk kültüründe selamlaşma ve vedalaşma ifadelerinin anlamlı kültürel göstergeler olarak taşıdıkları millî kültürel niteliklerini şekillendiren temel dinamiğin ve bu anlamda bunların temel motivasyonlarının büyük oranda, "iyi dilekte bulunma, iyi dileklerini bildirme" kaynaklı olduğunu göstermektedir. Dolayısıyla da selam ve veda sözlerinin, Türk kültür tarihinde iyi dilek bildirme sözleri olarak alkışlarla yakın bir ilişki içerisinde bulunduğunun değerlendirilmesi, ya da en azından bu sözlerle ilişkileri bakımından ayrıca incelenmesinin gerekliliği vurgulanmalıdır.

\section{Sonuç}

Dil ve kültür arasındaki etkileşimlerin belirgin olduğu alanlar arasında, gündelik yaşamdaki rutin iletişim biçimleri ve bunlara bağlı olarak şekillenen konuşma tutumları yer almaktadır. Selamlaşma ve vedalaşma, gündelik yaşamın ve iletişim rutinlerinin başlıca örnekleri ve anlamlı kültürel göstergeler olarak bütün toplumlarda dil ve kültürün önemli yansımaları olarak ön plana çıkmaktadır. Bu iletişim biçimleri ve kültürel unsurlar, Türk kültür tarihinde de özellikle gündelik yaşama ait birikimlerin önemli bir yönünü temsil etmektedir ve bu yönüyle araştırılmaya değerdir.

Türklerin tarihin eski dönemlerinden günümüze kadar aman, bayar, boy, çolugar, esen, iyi/yahşi, mindi, sağ gibi Türkçe ve Moğolca kaynaklı ve hayr, hoş, selam, veda, razı gibi Arapça veya Farsça kaynaklı sözcükler etrafinda oluşturdukları ifadeleri selamlaşma ve vedalaşma sırasında yaygın olarak kullanmış oldukları görülmektedir. Bu ifadelerde genel olarak, tıpkı diğer toplumlarda olduğu gibi; "dostluk", "zararsızlık" bilgisinin ve "sağlık", "esenlik", "iyilik", "mutluluk", "uğurluluk" ve "kutluluk" isteklerinin ön plana çıkartılmış olduğu gözlemlenmektedir.

Türklerin İslamiyet ile tanışmasıyla kullanılmaya başlanan Arapça selam, merhaba, veda, hoş sözcükleri ve bu sözcüklerden türetilmiş olan çeşitli ifadelerin, başta Türkiye ve Batı Türklüğü olmak üzere, Türk topluluklarının selamlaşma ifadesi olarak kullanım tutumlarında diğer ifadelere baskın geldiği anlaşılmaktadır. Bu baskınlığa rağmen bazı boylar arasında, özellikle Kazak, Kırgız ve Özbek Türklerinde Arapça ve Farsça kelimelerden türetilen bu sözcük ve ifadelerle birlikte Moğolca ve Türkçe kaynaklı selamlaşma sözcükleri- 
nin de kullanılmaya devam ettiği görülmektedir. İslamiyet ile temasları olmayan ya da görece olarak daha geç dönemlerde olan ve dolayısıyla da Arapça, Farsça sözcükleri sınırlı örnekler dışında bünyesine çok fazla almamış olan Altay, Saha ve Tuva Türkleri gibi bazı Türk toplulukları arasında ise selamlaşmanın ağırlıklı olarak Türkçe ve Moğolca kaynaklı sözcüklerle sürdürülmekte olduğu anlaşılmaktadır.

Türk kültür tarihinde ve günümüzde Türk boyları arasında selamlaşma süreçlerinde kullanıldığı tespit edilen tüm bu tutum, sözcük ve ifadeler dışında da tercih edilmiş olan/tercih edilen daha pek çok tutum ve ifadenin varlığ kuvvetle muhtemeldir. Gündelik iletişimin sağlanmasında yaygın ve rutin bir şekilde başvurulan tüm bu sözcük, tutum, davranış ve ifadeler ve bunlardaki değişim ve dönüşümler, bir toplumun kültürünü, o kültürü şekillendiren bireyleri, bütün bunların tarihî süreçteki birbirleriyle ve diğer kültürlerle olan etkileşimlerini de temsil ederek yansıtması bakımından, dil ve kültür çalışmaları için önem taşımaktadır. Kültür ve dildeki çeşitli değişmelerin bir sonucu olarak Türklerin "selamlaşma" ve "vedalaşma" tutumlarının, bu tutumlardaki değişimin kültürel boyutlarının, selamlaşma eyleminde iç içe geçmiş hâldeki bütünleşik görünümlerin daha yakından ve kapsamlı bir şekilde takip edilmesi, Türklerin toplumsal yaşamları hakkında yapılacak art ve eş zamanlı, ayrıntılı ve disiplinler arası yeni çalışmalarla mümkün olacaktır. 


\section{Ek Tablo:}

Türk Lehçelerinde Selamlaşma ve Vedalaşma İşlevinde Kullanılan Sözcük ve İfadeler

\begin{tabular}{|c|c|c|c|c|c|c|c|c|c|c|c|c|c|}
\hline 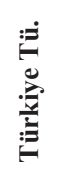 & 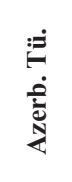 & 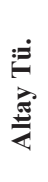 & 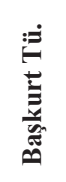 & 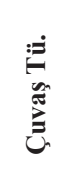 & 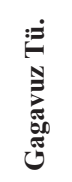 & 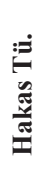 & 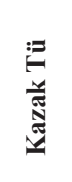 & 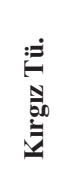 & 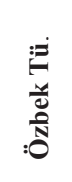 & 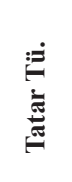 & $\begin{array}{l}: \dot{\Xi} \\
\stackrel{\pi}{\Xi} \\
\stackrel{\Xi}{E}\end{array}$ & 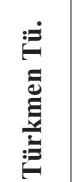 & 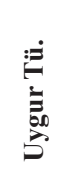 \\
\hline $\begin{array}{l}\tilde{\overline{0}} \\
\text { 品 }\end{array}$ & $\begin{array}{l}\text { 芯 } \\
\text { 䓌 } \\
\text { E్ }\end{array}$ & 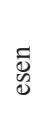 & 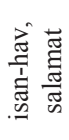 & & & & 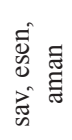 & 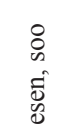 & 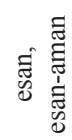 & 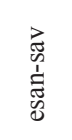 & & 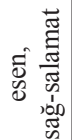 & 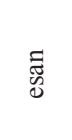 \\
\hline 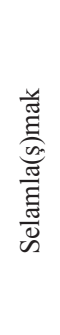 & 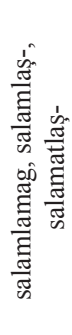 & 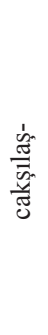 & 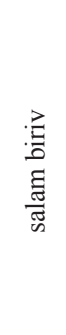 & & 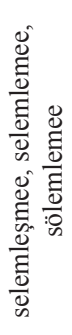 & 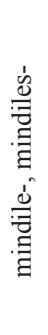 & 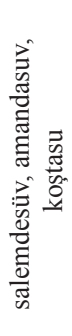 & 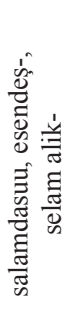 & 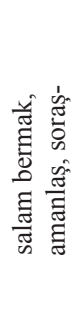 & 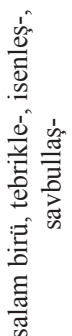 & 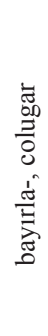 & 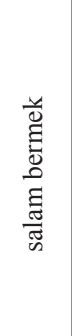 & 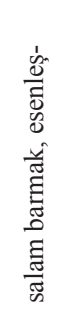 \\
\hline 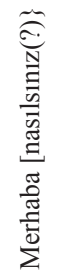 & 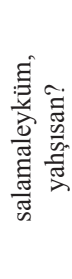 & 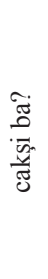 & 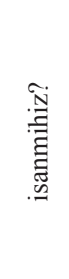 & 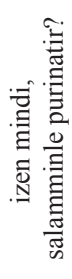 & & & 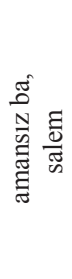 & 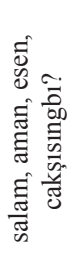 & 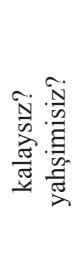 & 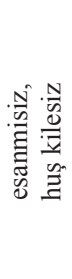 & $\frac{\bar{y}}{\mathrm{e}}$ & 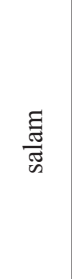 & 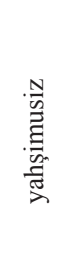 \\
\hline 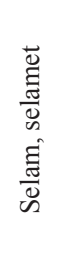 & 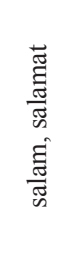 & 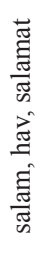 & & 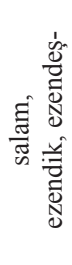 & 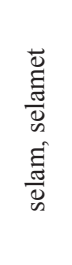 & 刍 & 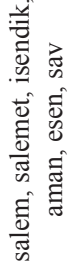 & 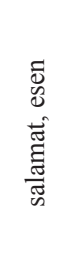 & 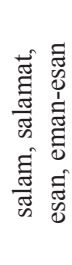 & 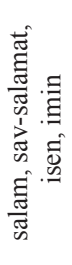 & $\frac{\bar{y}}{\mathrm{~d}}$ & 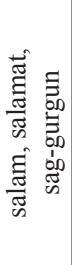 & 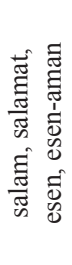 \\
\hline
\end{tabular}


Türk Kültüründe "Selamlaşma” ve "Vedalaşma” Hakkında Genel Bir Değerlendirme

\begin{tabular}{|c|c|c|c|c|c|c|c|c|c|c|c|c|c|}
\hline 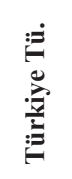 & 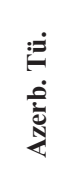 & 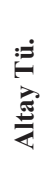 & 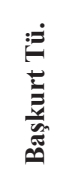 & 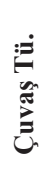 & 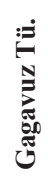 & 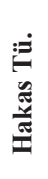 & 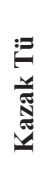 & 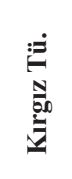 & 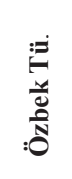 & 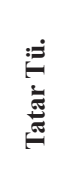 & 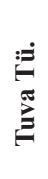 & 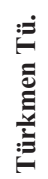 & 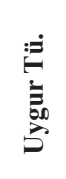 \\
\hline 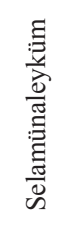 & 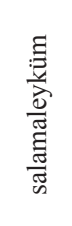 & & 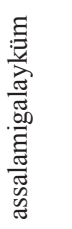 & 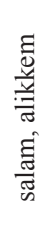 & & & 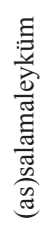 & 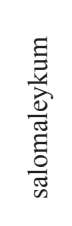 & 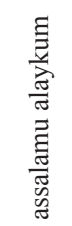 & 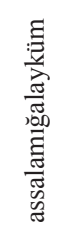 & & 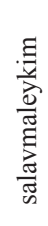 & 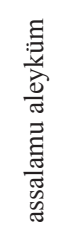 \\
\hline 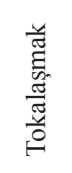 & 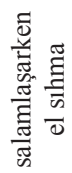 & & 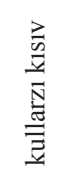 & & 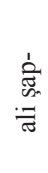 & & 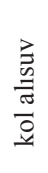 & 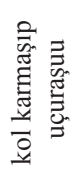 & 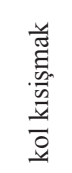 & 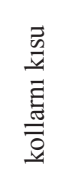 & & 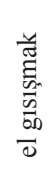 & 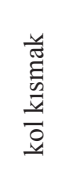 \\
\hline 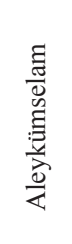 & 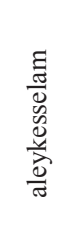 & & 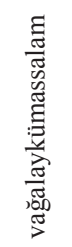 & $\begin{array}{l}\text { च } \\
\frac{\vec{y}}{\bar{z}}\end{array}$ & & & 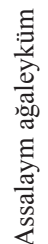 & 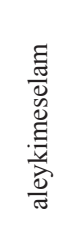 & 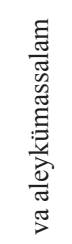 & 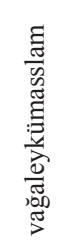 & & 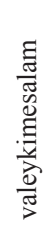 & 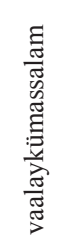 \\
\hline 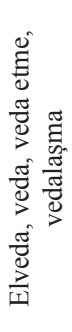 & 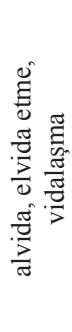 & & 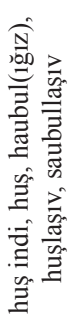 & . & & & 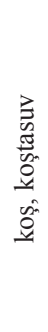 & 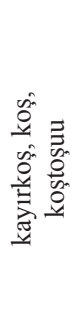 & 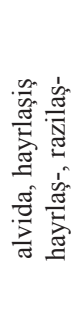 & 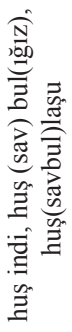 & & 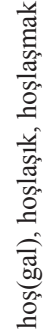 & 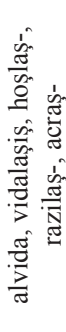 \\
\hline
\end{tabular}




\begin{tabular}{|c|c|c|c|c|c|c|c|c|c|c|c|c|c|}
\hline 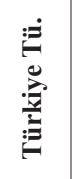 & 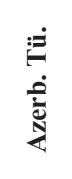 & 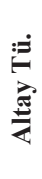 & 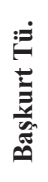 & 葛 & 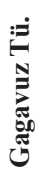 & 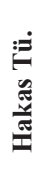 & 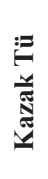 & 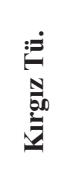 & 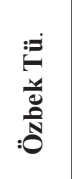 & 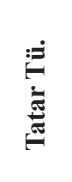 & 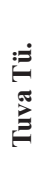 & 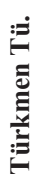 & 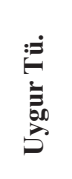 \\
\hline 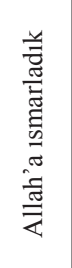 & 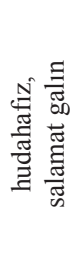 & & 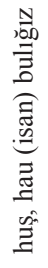 & 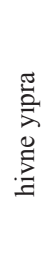 & & & 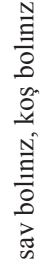 & 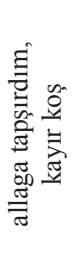 & 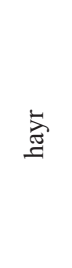 & 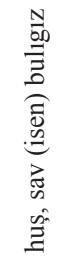 & & 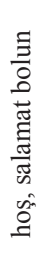 & 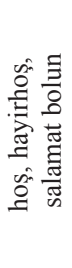 \\
\hline 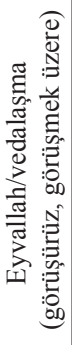 & 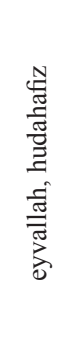 & & 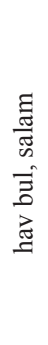 & & 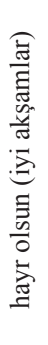 & & 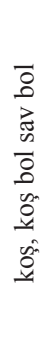 & 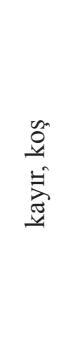 & 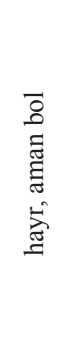 & 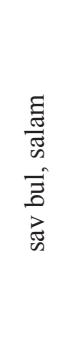 & 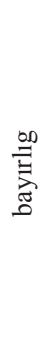 & 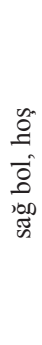 & 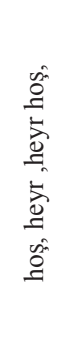 \\
\hline 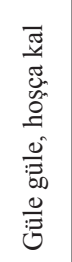 & 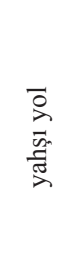 & & 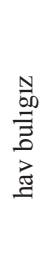 & 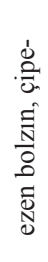 & & 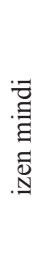 & 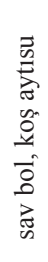 & 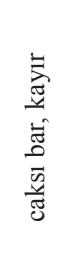 & 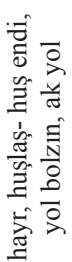 & 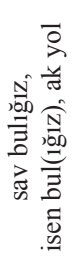 & 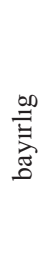 & $\stackrel{\infty}{8}$ & 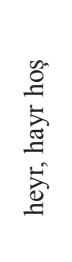 \\
\hline
\end{tabular}




\section{Kaynaklar}

AÇA, Mehmet (2006), “Tıva Destan ve Masallarının Araştırılmasında Tür Sorunu”, Millî Folklor, S 72, s. 85-94.

AÇA, Mehmet (2007), Tıva Halk Masalları, Konya, Kömen Yayınları.

AKALIN, Şükrü Hâluk (2008), Binyıl Önce Binyıl Sonra Kâşgarlı Mahmud ve Dîvânu Lugâti tTürk, Ankara, TDK Yayınları.

ALTAYLI, Seyfettin (1994a), Azerbaycan Türkçesi Sözlüğü I (A-Heman), İstanbul, Millî Eğitim Yayınevi.

ALTAYLI, Seyfettin (1994b), Azerbaycan Türkçesi Sözlüğ̈̈ II (Hemaset-Züyültü), İstanbul, Millî Eğitim Yayınevi.

ARIKOĞLU, Ekrem (1991), Örnekli Hakasça-Türkçe Sözlük, Ankara, Akçağ Yayınları.

ATALAY, Besim (Çeviren), (1991), Dîvânü Lugâti 't-Türk Dizini "Endeks”, Cilt: 4, 3. Bask1, Ankara, Türk Tarih Kurumu Basımevi.

ATALAY, Besim (Çeviren), (1998), Dîvânü Lugâti t'-Türk Tercümesi, Cilt: I, 4. Bask1, Ankara, Ankara Üniversitesi Basımevi.

BASKAKOV, N. A. (1991), Gagauz Türkçesinin Sözlüğü (Yay. Haz.: İsmail Kaynak-A. Mecit Doğru), Ankara, Semih Ofset.

BAYNIZAROV, Ayabek-Canar Bayniyazova (1968), Türikçe-Kazakça Sözdik (Ed.: Kenan Koç), Almatı.

CAFEROĞLU, Ahmet (1968), Eski Uygur Türkçesi Sözlüğü, Ankara, TDK Yayınları.

CLAUSON, Sir Gerard (1972), An Etymological Dictionary of Pre-Thirteenth-Century Turkish, Oxford, Clarendon Press.

COULMAS, Florian (1979), "On the Sociolinguistic Relevance of Routine Formuleae", Journal of Pragmatics, S 3, s. 239-266.

ÇETIN, Çulpan Zaripova (2007), "Tatar Türklerinde Mitolojik Varlıklarla İlgili Mitler ve İnanışlar (İyelikler ve Yaratıklar)”, Bilig S 43, s. 1-32.

DİLEK, İbrahim (2007), Altay Destanları III, Ankara, TDK Yayınları.

DIRKS, William-Temur Davranov (2005), Özbekçe-Ingilizce Lügat, The Central Asian Heritage Group.

DUNDES, Alan (1965), "What is Folklore”, The Study of Folklore, New Jersey, Prencite-Hall, ss. 1-3.

DUNDES, Alan (1966), "The American Concept of Folklore”, Journal of the Folklore Institute, 3 (3) [Special Issue: The Yugoslav-American Folklore Seminar]: 226-249.

DURANTI, Alessandro (1992), "Language and Bodies in Social Space: Samoan Ceremonial Greetings", American Anthropologist, 94: 657-691.

DURANTI, Alessandro (1997), "Universal and Culture-Spesific Properties of Greetings", Journal of Linguistic Anthropology, 7(1): 63-97.

EMİROĞLU, Kudret (2012), Gündelik Hayatımızın Tarihi, 2. Bask1, İstanbul, Türkiye İş Bankası Yayınları.

ERCILASUN, Ahmet Bican (1991), Karşılaştırmalı Türk Lehçeleri Sözlüğü (Kılavuz Kitap) I, Ankara, Kültür Bakanlığı Yayınları.

ERGIN, Muharrem (2004), Dede Korkut Kitabı I. Giriş-Metin-Faksimile, 5. Bask1, Ankara, TDK Yayınları. 
ERGIN, Muharrem (2006), Orhun Abideleri, 37. Bask1, İstanbul, Boğaziçi Yayınları.

ERGUN, Pervin (2010), Hakas Destancılık Geleneği ve Ay Huucın, Konya, Kömen Yayınları.

EROL, Çiğdem (2007), Türkiye Türkçesinde Kalıp Sözler Üzerine Bir İnceleme, İstanbul Üniversitesi Sosyal Bilimler Enstitüsü Yayımlanmamış Yüksek Lisans Tezi.

EYÜBOĞLU, İsmet Zeki (1991), Türk Dilinin Etimoloji Sözlüğ̈̈, 2. Bask1, İstanbul, Gözlem Matbaacilık.

FAROQHI, Suraiya (2002), Osmanlı Kültürü ve Gündelik Yaşam. Ortaçağdan Yirminci Yüzyıla, (Çeviren: Elif Kılıç), İstanbul, Tarih Vakfı Yurt Yayınları.

FEDAKÂR, Selami (2006), "Sözlü Kültür Teorisi Bağlamında Özbek Destan Anlatıcıları”, Mitten Meddaha Türk Halk Anlatıları Uluslararası Sempozyumu Bildirileri, Ankara, Gazi Üniversitesi Türk Halk Bilimi Araştırma ve Uygulama Merkezi Yayınları, s. 213-222.

GANIYEV, Fuat (1997), Tatarca Türkçe Sözlük, Kazan, İnsan Yayınevi.

GENÇ, Reşat (1997), Kâşgarlı Mahmud'a Göre XI. Yüzyılda Türk Dünyası, Ankara, Türk Kültürünü Araştırma Enstitüsü Yayınları.

HAMZAEVA, M. Ya (1962), Slovar Turkmenskogo Yazıka, Aşkabat, Türkmenistan SSR Bilimler Akademisi Yayınları.

HARTLEY, Peter (2010), Kişilerarası İletişim (Çev.: Ülkü Doğanay vd.), Ankara, İmge Kitabevi Yayınlar1.

İÇÖZ, Ayşe (2008), Arap Dilinde Hidayet-Dalalet, Salat ve Selam Kelimelerine Semantik Yaklaşım, Marmara Üniversitesi Sosyal Bilimler Enstitüsü Yayımlanmamış Yüksek Lisans Tezi.

KAFESOĞLU, İbrahim (2005), Türk Millî Kültürü, 25. Bask1, İstanbul, Ötüken Neşriyat.

KARADAYI, Hürriyet (2008), “Türkçede Kalıp Sözler”, Bilig, S 4: s. 89-110.

KARTARI, Asker (2003), Farklılıklarla Yaşamak. Kültürlerarası Illetişim, Ankara, Şahin Matbaası.

KOÇ, Kenan (2003), Kazakça-Türkçe Sözlük, Ankara, Akçağ Yayınları.

LA BARRE, Weston (1972) "Kültürden Gelen Davranışlar: Selamlaşma Örnekleri”" (Communication in Face to Face Interaction adlı kitap içinde bölüm) (Çeviren: Yalçın İzbul), 1972 (Çevirinin internet versiyonunun yayını: 2007), (Erişim Adresi: http://www. ingilizce-ders.com/ceviri-tercume/beden-dili/beden-dili.htm), 22/04/2012, sa. 10:40.

LESSING, Ferdinand D. (2003a), Moğolca-Türkçe Sözlük I (A-N), (Çeviren: Günay Karaağaç), Ankara, TDK Yayınları.

LESSING, Ferdinand D. (2003b), Moğolca-Türkçe Sözlük I (O-Z), (Çeviren: Günay Karaağaç), Ankara, TDK Yayınları.

MA’RUFOV, Z. M. (1981a), Özbek Tilining İzahli Lügati-I (A-P), Moskova, Rus Tili Neşriyatı. MA’RUFOV, Z. M. (1981b), Özbek Tilining İzahli Lügati-II (C-X), Moskova, Rus Tili Neşriyatı.

NASKALİ, Emine Gürsoy-Muvaffak Duranlı (Yay. Haz.), (1999), N. A. Baskakov ile T. M. Toşçakova'nın Oyrotsko-Russkiy Slovarı'ndan Genişletilmiş Altayca-Türkçe Sözlük, Ankara, TDK Yayınları.

NASKALİ, Emine Gürsoy (Haz.), (2007), Hakasça Türkçe Sözlük, Ankara, TDK Yayınları.

NECİPOVIÇ, Necip Emir (1995), Yeni Uygur Türkçesi Sözlüğü, (Çev.: İklil Kurban), Ankara, TDK Yayınları. 
NEMETH, Gyula (1990), Kumuk ve Balkar Lehçeleri Sözlü̆̈̈̈, (Çev.: Kemal Aytaç), Ankara, Kültür Bakanlığı Yayınları.

ÖGEL, Bahaeddin (2000), Türk Kültür Tarihine Giriş. Türklerde Köy ve Şehir Hayatı. Göktürklerden Osmanlılara, Cilt I, 4. Bask1, Ankara, Kültür Bakanlığı Yayınları.

ÖGEL, Bahaeddin (2001), Türk Kültürünün Gelişme Çağlarl, İstanbul, Türk Dünyas1 Araştırmalar Vakfi.

ÖLMEZ, Mehmet (2007), Tuvacanın Söz Varlığı. Eski Türkçe ve Moğolca Denkleriyle, Wiesbaden, Harrassowitz Verlag.

ÖNER, Mustafa (2009), Kazan-Tatar Türkçesi Sözlüğü, Ankara, TDK Yayınları.

ÖZTÜRK, Fatih (Haz.), "Selamlaşmanın Tarihi”, (Erişim Adresi: http://www.forumgercek. com/archive/index.php/t-42771.html), 29/01/2012, sa. 14.50.

PAASONEN, H. (1950), Çuvaş Sözlüğ̈̈, İstanbul, İbrahim Horoz Basımevi.

PALMBAH, A. A. (1955), Tuvinsko-Russkiy Slovar', Moskova.

REICHL, Karl (2002), Türk Boylarının Destanları (Gelenekler, Şiirler, Şiir Yapısı), (Çev.: Metin Ekici), Ankara, TDK Yayınları.

SAGINBAYEVA, Burul (2013), "Kırgız Dilindeki Vedalaşma Sözlerinin Ulusal Özellikleri” Yayımlanmamış Makale.

SELÇUK, Ayhan (2005), "Kültürlerarası İletişim Açısından Gündelik İletişim Davranışları", Selçuk Üniversitesi Sosyal Bilimler Enstitüsü Dergisi, S 13, s. 1-17.

SHAKHMAYEV, Sergey (1994), Tatar-English/English-Tatar Dictionary, New York, Hippocrene Books.

SÜMER, Faruk (1980), Oğuzlar (Türkmenler). Tarihleri, Boy Teşkilatı, Destanları, 3. Bask1, İstanbul, Elif Ofset.

TEKINN, Talat, vd. (1995), Türkmence-Türkçe Sözlük, İstanbul, Simurg Kitapçılık.

TOELKEN, Barre (1996), The Dynamics of Folklore, Utah, Utah State University Press.

TOGAN, İsenbike (2006), Çin Kaynaklarında Türkler. Eski Tang Tarihi (Chiu T'ang-shu 194a) Türkler Bölümü (Açıklamalı Metin Neşri), Ankara, TTK Yayınları.

TOLAN, Muhammet Bilal (2006), Kur'an'da Selam Kavramının Semantik Analizi, Firat Üniversitesi Sosyal Bilimler Enstitüsü Yayımlanmamış Yüksek Lisans Tezi.

VASILIEV, Yuri (1995), Türkçe-Sahaca (Yakutça) Sözlük, Ankara, TDK Yayınları.

YAZICI, Hikmet (2012), "Kişilerarası İlişkilerde Sözsüz İletişim”, Kişilerarası İlişkiler ve Etkili İletişim, (Ed.: Alim Kaya), 4. Bask1, Ankara, Pegem Akademi, s. 157-172.

YUDAHIN, K. K. (1998), Kırgız Sözlüğü (SSCB Bilimler Akademisinin Doğuyu İnceleme Enstitüsü), (Çev.: Abdullah Taymas), (I. Cilt), 4. Bask1, Ankara, Ankara Üniversitesi Basımevi.

http://www.tdk.gov.tr/index.php?option=com_lehceler, 12/05/2012, sa. 20.45. 